\title{
Tahap Keberkesanan Gamifikasi Global Halal Game (GHG) Dalam Kalangan Peserta Program Halal Eksekutif Profesional

\author{
Effectiveness Level of Gamification Global Halal Game (GHG) Among Professional Halal Training \\ Programme Participants
}

Mohammad Najib Jaffar*, Azman Ab Rahman, Mohamad Anwar Zakaria, Mursyid Junaidi Mohd Faisal Yeap, Muhammad Faiz Abd. Shakor

Universiti Sains Islam Malaysia, Bandar Baru Nilai, 71800 Nilai, Negeri Sembilan.

*Corresponding author: najib@usim.edu.my

\section{Article history}

Received: 2020-03-07 Received in revised form: 2020-08-06 Accepted: 2020-08-08 Published online: 2020-10-30

\begin{abstract}
Gamification is a part of teaching aids based on flexible education relevant to the current 21st Century Learning. This study aimed at assessing the effectiveness of the Global Halal Game (GHG) in education. The use of quantitative method involved the distribution of questionnaires to 43 respondents who participated in the Professional Halal Training Programme - Certificate of Professional Halal Executive (PHEP) 2018. In general, this study found that the effectiveness level of GHG in education was good. The result of the study can also become a benchmark for the development of gamification-based innovation product, which can improve and enhance other innovation products in fields that are less emphasised. This can benefit the Muslim community, in particular, and the public, in general.
\end{abstract}

Keywords: Gamification, teaching aids, flexible education, Global Halal Game, innovation.

\begin{abstract}
Abstrak
Gamifikasi merupakan salah satu bahan bantu mengajar pendidikan fleksibel yang signifikan dengan Pembelajaran Abad Ke-21 kini. Kajian ini bertujuan untuk mengukur tahap keberkesanan Global Halal Game (GHG) dalam pendidikan. Metodologi yang digunakan dalam kajian ini ialah kaedah kuantitatif melalui soal selidik yang diedarkan kepada empat puluh tiga (43) orang responden yang mengambil bahagian dalam Professional Halal Training Programme - Certificate of Professional Halal Executive (PHEP) 2018. Hasil kajian mendapati bahawa secara umumnya tahap keberkesanan GHG dalam Pendidikan adalah di tahap yang baik. Hasil kajian ini juga boleh dijadikan penanda aras bagi pihak pembangun produk inovasi berciri gamifikasi untuk melakukan lebih penambahbaikan dan penghasilan produk inovasi lain untuk bidang-bidang lain yang masih kurang diberi penekanan untuk kebaikan masyarakat Islam khususnya dan masyarakat umum amnya.
\end{abstract}

Kata Kunci: Gamifikasi, bahan bantu mengajar, pendidikan fleksibel, Global Halal Game, inovasi. 


\subsection{PENDAHULUAN}

Kepesatan pembangunan industri halal hari ini telah meletakkan Malaysia di barisan hadapan sebagai negara peneraju industri halal global. Hal ini bukanlah sekadar harapan dan hasrat yang terpendam kerana umum mengetahui, Persijilan Halal negara telah mendapat pengiktirafan di peringkat global. Berdasarkan Thomson Reuters State of Global Islamic and Economic Report 2015/2016, Malaysia telah dinobatkan sebagai negara Islam terbaik dalam kalangan 73 buah negara, yang telah berjaya membangunkan ekonominya dengan maju (Azman Mahmud, 2016). Dalam laporan yang sama juga, turut direkodkan bahawa Malaysia berada di tempat pertama dalam kategori Makanan Halal, Kewangan Islam dan Pelancongan Halal serta berada di dalam kedudukan lima negara teratas bagi kategori farmaseutikal dan kosmetik. Perkara ini amat jelas menunjukkan pertumbuhan yang pesat industri halal negara dan keterbukaan masyarakat berbilang kaum bukan sahaja di negara ini, bahkan dunia sendiri yang menerima baik produk halal sebagai salah satu sumber utama keperluan harian mereka.

Ekosistem halal di negara ini dilihat telah memberi manfaat yang tidak sedikit kepada banyak syarikat ternama asing yang telah dibangunkan sejak lama dahulu. Sebagai contoh, syarikat-syarikat seperti Charoen Pokphand (CP) Holdings, Nestle, Kerry Ingredients, PureCircle, Cargill, Adeka Foods, Rikevita, Kewpie, IFFCO, Kellogg dan Ajinomoto adalah antara syarikat gergasi luar negara yang telah menjadikan Malaysia sebagai pangkalan bagi pembuatan produk halal mereka (Azman Mahmud, 2016). Situasi ini jika diteliti bukan sahaja memberi manfaat kepada Malaysia dalam usaha menjadi Pusat Rujukan Global bagi Integriti dan Pusat Inovasi Produk dan Perdagangan melalui strategi yang digariskan di bawah Rancangan Malaysia Kesebelas (2016-2020), bahkan membuka pintu-pintu pelaburan yang sangat bermanfaat serta menyumbang kepada pembangunan ekonomi patuh Syariah negara.

Selain sumbangan kepada sektor pembuatan dan ekonomi, industri halal juga masih perlu memberi penumpuan kepada sektor pendidikan. Sektor pendidikan dalam industri halal amat penting kerana ia menjadi wadah dan pelantar asas dalam usaha memberi kesedaran kepada bukan sahaja pengguna bahkan pengusaha industri halal itu sendiri. Pendidikan kepenggunaan halal bermatlamat untuk memberikan kesedaran dan hak-hak pengguna berhubung dengannya (Aizat Jamaluddin et. al., 2012). Dalam usaha mencapai objektif ini, pelbagai pihak sama ada sektor kerajaan mahupun swasta berusaha menyediakan landasan yang terbaik melalui penawaran program-program pendidikan kepenggunaan halal yang komprehensif serta memenuhi keperluan aspek Syariah dan teknikalitinya.

Penggunaan modul-modul khas agensi penyedia perkhidmatan pendidikan kepenggunaan halal mahupun para akademia merupakan sumber rujukan bagi pembelajaran formal (Mohd Mahyeddin Mohd Salleh \& Mohammad Najib Jaffar, 2019). Namun, sebagai alternatif, pembelajaran secara santai dengan produk-produk inovasi pendidikan juga secara tidak langsung memberi manfaat dalam menyumbang kefahaman kepada pembelajaran di dalam kelas formal. Penggunaan alat permainan sebagai salah satu sumber mendapatkan ilmu merupakan antara kaedah pembelajaran abad moden yang menerapkan ciri-ciri pembelajaran secara santai tetapi masih mencapai objektif. Dalam memahami pendidikan kepenggunaan halal ini, antara alat yang dilihat dapat menyumbang kepada penjanaan ilmu secara santai adalah Global Halal Game (GHG) yang diinovasikan oleh penyelidik tempatan. GHG yang diperkenalkan ini telah mengetengahkan konsep gamifikasi dengan tujuan untuk meningkatkan kesedaran masyarakat seawal usia kanakkanak lagi berkaitan disiplin halal (kampusuols.com). 


\subsection{SOROTAN LITERATUR}

Keperluan Pendidikan abad ke-21 hari ini telah menggalakkan pelbagai inovasi dan ciptaan baharu dalam usaha menyampaikan maklumat serta pengetahuan kepada masyarakat amnya dan penuntut ilmu khususnya. Penciptaan kaedah dan cara baru dalam usaha penyampaian maklumat ini adalah bagi mengimbangkan antara potensi dan kemahiran dalam diri seseorang dengan pengetahuan yang dibina. Percambahan ilmu melalui kaedah didik hibur dilihat lebih sesuai diterapkan dengan generasi hari ini kerana perubahan pola pemikiran kanak-kanak hari ini yang berbeza dengan generasi sebelumnya. Kehendak kepada pembelajaran dalam masa yang sama boleh bermain memberi dorongan kepada perintis inovasi untuk membuat suatu inovasi yang sesuai dengan corak pemikiran masyarakat hari ini. Gamifikasi atau Gamification merupakan antara kaedah pembelajaran yang menggabungkan permainan dengan pembelajaran yang menjadi teknik dua serampang kepada pengguna dalam mendapatkan pengetahuan dalam masa yang sama berhibur secara santai.

Pengunaan istilah gamifikasi atau 'gamification' ini dilihat mula dikenali sekitar tahun 2002 dan dikatakan telah dipelopori oleh Nick Pelling yang merupakan seorang pengaturcara komputer dan pencipta permainan komputer Frak! (Nurkhamimi et. al., 2017). Pada tahun 2008, Brett Terill pula telah menggunakan terma ini di dalam blognya dan menghuraikan perkataan tersebut sebagai pengadaptasian mekanisma permainan ke dalam aturan web yang lain untuk meningkatkan penglibatan pelayar (Hamari, 2012). Istilah ini kemudian kembali popular sekitar tahun 2010 dan digunakan secara meluas dalam bidang perniagaan bagi tujuan merancakkan pemasaran syarikat. Di Malaysia, istilah gamifikasi dalam Pengajaran dan Pembelajaran (P\&P) sangat sinonim dengan konsep Pembelajaran Abad Ke-21 (PAK-21). Pendekatan gamifikasi dikatakan mempunyai potensi yang besar dalam bidang pendidikan kerana ia memberi ruang kepada penghasilan pembelajaran yang lebih inovatif dan fleksibel (Hsin-Yuan \& Soman, 2013). Hal ini turut disokong oleh Hussain, Tan \& Idris (2014) bahawa pendekatan gamifikasi yang diintegrasi dengan penerapan elemen permainan ini bukan sahaja dapat menstimulasi daya pemikiran, bahkan dapat meransang dan memotivasi pengamalnya.

Walaubagaimanapun, penerapan pembelajaran menggunakan kaedah gamifikasi ini dikatakan masih belum meluas pelaksanaannya. Berdasarkan carian penulis juga, laporan empirikal tentang keberkesanannya terhadap pembelajaran pelajar juga tidak banyak direkodkan. Hal ini berkemungkinan disebabkan beberapa cabaran dalam pelaksanaannya yang membataskan penggunaan kaedah gamifikasi dalam pembelajaran di Malaysia secara meluas. Hussain, Tan \& Idris (2014) menyatakan, penghasilan gamifikasi yang kurang berkualiti menjadi salah satu faktor mengapa kaedah gamifikasi kurang mendapat sambutan yang baik dalam pembelajaran di Malaysia. Rohaila \& Fariza (2017) pula berpendapat, pembina gamifikasi yang tidak mempunyai pengalaman dalam bidang pendidikan juga menjadi salah satu faktor keterbatasan ini. Perkara ini turut disokong oleh Cugelman (2013), dimana lambakan rekabentuk gamifikasi yang tidak meyakinkan bukanlah disebabkan oleh ralat fungsi permainan tersebut, tetapi kerana ia dibangunkan oleh mereka yang tidak mempunyai latar belakang dalam bidang pendidikan. Justeru, kekangan ini memberi pandangan bagaimana mungkin ia dapat diadaptasi sedangkan olahan format, struktur kandungan dan penceritaannya tidak menepati kehendak pasaran dan pembelajaran semasa (Noor et al, 2015).

Global Halal Game (GHG) merupakan sebuah produk inovasi yang dibangunkan oleh penyelidik yang mempunyai latar belakang bidang pendidikan selain berpengalaman luas dalam pembinaan produk inovasi pendidikan. Global Halal Game ini telah dibangunkan bertujuan untuk memberi nilai tambah kepada pemasaran bidang halal di negara termasuk memberi pendedahan dan kesedaran kepada masyarakat berkaitan industri halal melalui medium pembelajaran yang interaktif (Kampusuols.com). Menurut pembangunnya, GHG adalah permainan papan ilmiah yang 
dibangunkan secara khusus berasaskan sukatan pelajaran pendidikan Islam sekolah rendah dan sekolah menengah dan 'Manual Prosedur Pensijilan Halal Malaysia' bagi menerapkan konsep didik hibur dan interaktif dalam pendidikan halal (https://islamicgames.com.my). Bagi mengukur tahap keberkesanannya, kajian empirikal ini telah dijalankan dengan harapan ia dapat memberi nilai tambah kepada kajian-kajian lain berkaitan keberkesanan gamifikasi dalam pendidikan selain menjadi perintis kepada kajian-kajian lain yang berkaitan dengan keberkesanan penggunaan pelbagai media pengajaran dalam meningkatkan pengetahuan pelajar.

\subsection{METODOLOGI KAJIAN}

Bagi mengukur tahap keberkesanan GHG ini, instrumen penyelidikan yang digunakan dalam penyelidikan ialah soalan kaji selidik yang diedarkan kepada 43 responden secara rawak. Responden bagi kajian yang dipilih adalah mereka yang mengambil bahagian dalam Professional Halal Training Programme - Certification of Professional Halal Executive (PHEP) 2018. Soal selidik merupakan alat untuk mengumpul data bagi penyelidik sains sosial. Soal selidik sebenarnya tidak lebih daripada satu borang yang dibentuk khusus untuk mengisi maklumat yang diberikan oleh setiap responden dalam temu bual (Ahmad Mahdzan Ayob, 2005).

Bagi satu-satu kajian, satu soal selidik yang sama hendaklah digunakan untuk semua responden. Ini bagi memastikan keseragaman dalam jawapan yang diberikan. Keseragaman bermaksud semua mereka memberi jawapan yang sama, tetapi jawapan itu diletakkan di ruang yang sama bagi membolehkan pemprosesan data melalui komputer. Soalan itu juga dikemukakan mengikut urutan yang sama (Ahmad Mahdzan Ayob, 2005). Bagi kaedah analisis data pula, penyelidik menggunakan analisis data secara berkomputer menggunakan aplikasi SPSS versi 23 (Service Package for Science Social) untuk mendapatkan keputusan analisis yang tepat. Secara khususnya kajian ini akan menggunakan analisa diskriptif seperti statistik frekuensi dan peratusan.

\subsection{DAPATAN KAJIAN}

Kajian ini menggunakan kaedah kuantitatif dan proses pengumpulan data dilakukan melalui soal selidik yang diedarkan secara persampelan mudah kepada empat puluh tiga (43) orang responden. Soal selidik ini hanya mengandungi empat bahagian. Bahagian A adalah berkaitan dengan demografi atau maklumat peribadi responden. Bahagian B pula mengkehendaki responden menjawab dua belas (12) soalan yang berkaitan ciri-ciri fizikal permainan Global Halal Game berdasarkan pendapat responden dan seterusnya bahagian C pula merupakan sembilan (9) soalan berkaitan keberkesanan GHG dalam latihan para eksekutif halal. Manakala bahagian D adalah soalan tunggal berbentuk komen atau cadangan lanjut bagi tujuan penambahbaikan produk GHG pada masa hadapan. Dapatan kajian adalah seperti berikut:

\section{a) Jantina}

Jadual 1 di bawah menunjukkan seramai 13 (30.2\%) orang responden lelaki. Manakala seramai $30(69.8 \%)$ responden perempuan. Ini menunjukkan jumlah responden perempuan melebihi responden lelaki dengan perbezaan $69.8 \%$. 
Jadual 1 Jantina

\begin{tabular}{lcc}
\hline Jantina & Frekuensi & Peratusan \\
\hline Lelaki & 13 & 30.2 \\
Perempuan & 30 & 69.8 \\
Jumlah & 43 & 100.0 \\
\hline
\end{tabular}

\section{b) Umur}

Jadual 2 di bawah menunjukkan lingkungan umur yang menjadi responden untuk kajian ini. Sebanyak 19 orang responden yang berumur 23 tahun (44.2\%). Manakala, sebanyak 7 orang responden berumur 25 tahun dan yang selebihnya mencatatkan nilai yang paling rendah daripada kedua-dua umur ini.

Jadual 2 Umur

\begin{tabular}{lcc}
\hline Umur & Frekuensi & Peratusan \\
\hline & & \\
22 & 1 & 2.3 \\
23 & 19 & 44.2 \\
24 & 4 & 9.3 \\
25 & 7 & 16.3 \\
26 & 1 & 2.3 \\
28 & 1 & 2.3 \\
30 & 1 & 2.3 \\
31 & 4 & 9.3 \\
32 & 2 & 4.7 \\
34 & 1 & 2.3 \\
36 & 1 & 2.3 \\
39 & 1 & 2.3 \\
Jumlah & 1 & 100.0 \\
\hline
\end{tabular}

\section{c) Kategori Responden}

Jadual 3 di bawah menunjukkan seramai $23(53.5 \%)$ orang responden menuntut di institusi pengajian tinggi (IPT). Manakala seramai 20 (46.5\%) orang responden adalah orang umum.

Jadual 3 Kategori Responden

\begin{tabular}{lcc}
\hline Status & Frekuensi & Peratusan \\
\hline IPT & 23 & 53.5 \\
Umum & 20 & 46.5 \\
Jumlah & 43 & 100.0 \\
\hline
\end{tabular}




\section{d) Institusi Pengajian Tinggi}

Jadual 4 di bawah menunjukkan seramai 27 (62.8\%) orang responden menuntut di universiti asing. Manakala hanya $1(2.3 \%)$ orang responden yang menuntut di universiti kerajaan dan $15(34.9 \%)$ orang responden yang menuntut di universiti swasta.

Jadual 4 Institusi Pengajian Tinggi

\begin{tabular}{lcc}
\hline Status & Frekuensi & Peratusan \\
\hline UA & 27 & 62.8 \\
Kerajaan & 1 & 2.3 \\
Swasta & 15 & 34.9 \\
Jumlah & 43 & 100.0 \\
\hline
\end{tabular}

\section{e) Tahap Kesukaran}

Jadual 5 di bawah menunjukkan seramai 14 (32.6\%) orang responden adalah yang berpendapat tahap kesukaran permainan adalah sukar. Tambahan pula, mereka yang berpendapat permainan ini berada di tahap agak sukar adalah seramai $22(51.2 \%)$ orang responden. Manakala, masing-masing responden berpendapat tahap kesukaran adalah sederhana sukar dan tidak sukar adalah seramai $6(14 \%)$ dan $1(2.3 \%)$ orang responden.

Jadual 5 Tahap Kesukaran

\begin{tabular}{lcc}
\hline Status & Frekuensi & Peratusan \\
\hline Tidak Sukar & 1 & 2.3 \\
Sederhana Sukar & 6 & 14.0 \\
Agak Sukar & 22 & 51.2 \\
Sukar & 14 & 32.5 \\
Jumlah & 43 & 100.0 \\
\hline
\end{tabular}

\section{f) Arahan/ Peraturan Permainan}

Jadual 6 di bawah menunjukkan seramai $6(14 \%)$ orang responden bersetuju arahan peraturan adalah tidak kompleks. 9 (20.9\%) orang responden bersetuju arahan permainan adalah sederhana kompleks. Manakala 17 (39.5\%) orang responden berpendapat arahan peraturan adalah agak kompleks. Selain itu, $9(20.9 \%)$ orang responden berpendapat arahan peraturan adalah kompleks dan $2(4.7 \%)$ berpendapat arahan permainan adalah sangat kompleks.

Jadual 6 Arahan/Peraturan Permainan

\begin{tabular}{lcc}
\hline Status & Frekuensi & Peratusan \\
\hline Tidak Kompleks & 6 & 14.0 \\
Sederhana Kompleks & 9 & 20.9 \\
Agak Kompleks & 17 & 39.5 \\
Kompleks & 9 & 20.9 \\
Sangat Kompleks & 2 & 4.7 \\
Jumlah & 43 & 100.0 \\
\hline
\end{tabular}




\section{g) Keunikan}

Jadual 7 di bawah menunjukkan keunikan permainan Halal Game yang majoriti responden berpendapat permainan ini mempunyai keunikannya tersendiri. $20(46.5 \%)$ orang responden berpendapat permainan ini sangat berbeza berbanding permainan lain.

Jadual 7 Keunikan

\begin{tabular}{lcc}
\hline Status & Frekuensi & Peratusan \\
\hline Tiada Beza & 1 & 2.3 \\
Sederhana Beza & 2 & 4.7 \\
Agak Beza & 7 & 16.3 \\
Beza & 13 & 30.2 \\
Sangat Beza & 20 & 46.5 \\
Jumlah & 43 & 100.0 \\
\hline
\end{tabular}

\section{h) Tempoh Main}

Jadual 8 di bawah menunjukkan tempoh main untuk permainan yang dikaji. Responden yang berpendapat permainan mengambil masa yang lama adalah seramai 19 (44.2\%) dan merupakan peratusan yang tertinggi dalam kajian ini.

Jadual 8 Tempoh Main

\begin{tabular}{lcc}
\hline Status & Frekuensi & Peratusan \\
\hline Sederhana Lama & 2 & 4.7 \\
Agak Lama & 16 & 37.2 \\
Lama & 19 & 44.2 \\
Sangat Lama & 6 & 13.9 \\
Jumlah & 43 & 100.0 \\
\hline
\end{tabular}

\section{i) Grafik dan Ilustrasi}

Jadual 9 di bawah menunjukkan majoriti responden tertarik dengan grafik dan ilustrasi permainan ini. Hanya $4(9.3 \%)$ orang responden yang berpendapat agak suka dengan grafik dan ilustrasi yang diterapkan untuk permainan ini.

Jadual 9 Grafik dan Ilustrasi

\begin{tabular}{lcc}
\hline Status & Frekuensi & Peratusan \\
\hline Agak Suka & 4 & 9.3 \\
Suka & 20 & 46.5 \\
Sangat Suka & 19 & 44.2 \\
Jumlah & 43 & 100.0 \\
\hline
\end{tabular}

\section{j) Tahap Minat}

Jadual 10 di bawah menunjukkan majoriti responden menunjuk rasa minat yang tinggi ketika bermain permainan ini. Seramai $20(46.5 \%)$ orang responden yang menunjukkan sangat minat untuk permainan ini. 
Jadual 10 Tahap Minat

\begin{tabular}{lcc}
\hline Status & Frekuensi & Peratusan \\
\hline Agak Minat & 7 & 16.3 \\
Minat & 16 & 37.2 \\
Sangat Minat & 20 & 46.5 \\
Jumlah & 43 & 100.0 \\
\hline
\end{tabular}

\section{k) Konsep}

Jadual 11 di bawah menunjukkan majoriti responden menunjuk rasa minat yang tinggi ketika bermain permainan ini. Seramai $24(55.8 \%)$ orang responden yang bersetuju konsep permainan ini sangat menarik.

Jadual 11 Konsep

\begin{tabular}{lcc}
\hline Status & Frekuensi & Peratusan \\
\hline Agak Menarik & 4 & 9.3 \\
Menarik & 15 & 34.9 \\
Sangat Menarik & 24 & 55.8 \\
Jumlah & 43 & 100.0 \\
\hline
\end{tabular}

\section{1) Keinginan Main Lagi}

Jadual 12 di bawah menunjukkan majoriti responden mempunyai keinginan yang tinggi untuk bermain lagi. Hanya $1(2.3 \%)$ orang responden yang tidak berminat untuk bermain lagi permainan ini.

Jadual 12 Keinginan Main Lagi

\begin{tabular}{lcc}
\hline Status & Frekuensi & Peratusan \\
\hline Tidak Berkeinginan & 1 & 2.3 \\
Agak Berkeinginan & 8 & 18.6 \\
Berkeinginan & 14 & 32.6 \\
Sangat Berkeinginan & 20 & 46.5 \\
Jumlah & 43 & 100.0 \\
\hline
\end{tabular}

\section{m) Tahap Interaksi}

Jadual 13 di bawah menunjukkan majoriti responden berpendapat permainan ini memberikan kesan interaksi yang aktif. Hanya $2(4.7 \%)$ orang responden yang memberikan respon yang agak aktif. 
Jadual 13 Tahap Interaksi

\begin{tabular}{lcc}
\hline Status & Frekuensi & Peratusan \\
\hline Agak Aktif & 2 & 4.7 \\
Aktif & 10 & 23.3 \\
Sangat Aktif & 31 & 72 \\
Jumlah & 43 & 100.0 \\
\hline
\end{tabular}

\section{n) Tempoh Masa Menunggu}

Jadual 14 di bawah menunjukkan $4(9.3 \%)$ orang responden berpendapat tempoh masa menunggu permainan ini adalah sangat lama. Manakala 9 (20.9\%) orang responden berpendapat tidak lama.

Jadual 14 Tempoh Masa Menunggu

\begin{tabular}{lcc}
\hline Status & Frekuensi & Peratusan \\
\hline Tidak Lama & 9 & 20.9 \\
Sederhana Lama & 5 & 11.6 \\
Agak Lama & 12 & 27.9 \\
Lama & 13 & 30.2 \\
Sangat Lama & 4 & 9.3 \\
Jumlah & 43 & 100.0 \\
\hline
\end{tabular}

\section{o) Saiz Permainan} agak besar.

Jadual 15 di bawah menunjukkan majoriti responden berpendapat permainan ini bersaiz

Jadual 15 Saiz Permainan

\begin{tabular}{lcc}
\hline Status & Frekuensi & Peratusan \\
\hline Tidak Besar & 6 & 14.0 \\
Sederhana Besar & 5 & 11.6 \\
Agak Besar & 24 & 55.8 \\
Besar & 6 & 14.0 \\
Sangat Besar & 2 & 4.7 \\
Jumlah & 43 & 100.0 \\
\hline
\end{tabular}

\section{p) Saiz Teks}

Jadual 16 di bawah menunjukkan majoriti responden berpendapat saiz teks yang digunakan untuk permainan ini adalah agak besar. 
Jadual 16 Saiz Teks

\begin{tabular}{lcc}
\hline Status & Frekuensi & Peratusan \\
\hline Tidak Besar & 1 & 2.3 \\
Sederhana Besar & 7 & 16.3 \\
Agak Besar & 25 & 58.1 \\
Besar & 10 & 23.3 \\
Jumlah & 43 & 100.0 \\
\hline
\end{tabular}

q) Tahap Pemahaman

Jadual 17 di bawah menunjukkan majoriti responden bersetuju permainan ini memberikan kesan yang baik terhadap tahap kefahaman berkenaan dengan kajian ini.

Jadual 17 Tahap Pemahaman

\begin{tabular}{lcc}
\hline Status & Frekuensi & Peratusan \\
\hline Agak Baik & 4 & 9.3 \\
Baik & 18 & 41.9 \\
Sangat Baik & 21 & 48.8 \\
Jumlah & 43 & 100.0 \\
\hline
\end{tabular}

\section{r) Pengetahuan tentang llmu Halal Meningkat}

Jadual 18 di bawah menunjukkan majoriti responden bersetuju permainan ini memberikan peningkatan pengetahuan tentang ilmu halal.

Jadual 18 Peningkatan Pengetahuan Tentang Ilmu Halal

\begin{tabular}{lcc}
\hline Status & Frekuensi & Peratusan \\
\hline Agak Setuju & 4 & 9.3 \\
Setuju & 27 & 62.8 \\
Sangat Setuju & 12 & 27.9 \\
Jumlah & 43 & 100.0 \\
\hline
\end{tabular}

\section{s) Minat Meningkat}

Jadual 19 di bawah menunjukkan majoriti responden berpendapat permainan ini memberikan peningkatan minat terhadap ilmu halal.

Jadual 19 Peningkatan Minat

\begin{tabular}{lcc}
\hline Status & Frekuensi & Peratusan \\
\hline Agak Setuju & 2 & 4.7 \\
Setuju & 24 & 55.8 \\
Sangat Setuju & 17 & 39.5 \\
Jumlah & 43 & 100.0 \\
\hline
\end{tabular}




\section{t) Kandungan Merangkumi Sukatan Pelajaran}

Jadual 20 di bawah menunjukkan majoriti responden bersetuju kandungan permainan ini merangkui sukatan pelajaran. Hanya $1(2.3 \%)$ orang responden yang memberikan jawapan sederhana setuju.

Jadual 20 Kandungan Merangkumi Sukatan Pelajaran

\begin{tabular}{lcc}
\hline Status & Frekuensi & Peratusan \\
\hline Sederhana Setuju & 1 & 2.3 \\
Agak Setuju & 5 & 11.6 \\
Setuju & 20 & 46.5 \\
Sangat Setuju & 17 & 39.5 \\
Jumlah & 43 & 100.0 \\
\hline
\end{tabular}

\section{u) Mampu Kuasai Teori Secara Keseluruhan}

Jadual 21 di bawah menunjukkan majoriti responden bersetuju mereka mampu kuasai teori secara keseluruhan dengan pendedahan akan permainan ini.

Jadual 21 Mampu Kuasai Teori Secara Keseluruhan

\begin{tabular}{lcc}
\hline Status & Frekuensi & Peratusan \\
\hline Sederhana Setuju & 3 & 7.0 \\
Agak Setuju & 12 & 27.9 \\
Setuju & 19 & 44.2 \\
Sangat Setuju & 9 & 20.9 \\
Jumlah & 43 & 100.0 \\
\hline
\end{tabular}

\section{v) Mahir Ilmu Halal Lepas GHG}

Jadual 22 di bawah menunjukkan $16(37.2 \%)$ orang responden memberikan jawapan agak setuju akan mahir ilmu halal selepas GHG. Manakala 6 (14\%) orang responden yang memberikan jawapan sangat setuju.

Jadual 22 Mahir Ilmu Halal Lepas GHG

\begin{tabular}{lcc}
\hline Status & Frekuensi & Peratusan \\
\hline Agak Setuju & 16 & 37.2 \\
Setuju & 21 & 48.8 \\
Sangat Setuju & 6 & 14.0 \\
Jumlah & 43 & 100.0 \\
\hline
\end{tabular}




\section{w) Semua Topik Terkandung dalam GHG}

Jadual 23 di bawah menunjukkan 3 (7\%) orang responden memberikan respon sederhana setuju terhadap item semua topik terkandung dalam GHG. Manakala, seramai 13 (30.2\%) orang responden yang menyatakan sangat setuju akan item ini.

Jadual 23 Semua Topik Terkandung Dalam GHG

\begin{tabular}{lcc}
\hline Status & Frekuensi & Peratusan \\
\hline Sederhana Setuju & 3 & 7.0 \\
Agak Setuju & 13 & 30.2 \\
Setuju & 14 & 32.6 \\
Sangat Setuju & 13 & 30.2 \\
Jumlah & 43 & 100.0 \\
\hline
\end{tabular}

\section{x) Bahan Didik Libur}

Jadual 24 di bawah menunjukkan majoriti responden berpendapat setuju dan sangat setuju terhadap item bahan didik hibur apabila memberikan masing-masing mempunyai jumlah responden yang sama iaitu 17 (39.5\%) orang responden.

Jadual 24 Bahan Didik Hibur

\begin{tabular}{lcc}
\hline Status & Frekuensi & Peratusan \\
\hline Agak Setuju & 9 & 20.9 \\
Setuju & 17 & 39.5 \\
Sangat Setuju & 17 & 39.5 \\
Jumlah & 43 & 100.0 \\
\hline
\end{tabular}

\section{y) Alternatif Bahan Pendidikan Permainan Islamik}

Jadual 25 di bawah menunjukkan majoriti responden bersetuju terhadap item alternatif bahan pendidikan permainan Islamik.

Jadual 25 Alternatif Bahan Pendidikan Permainan Islamik

\begin{tabular}{lcc}
\hline Status & Frekuensi & Peratusan \\
\hline Agak Setuju & 3 & 7.0 \\
Setuju & 19 & 44.2 \\
Sangat Setuju & 21 & 48.8 \\
Jumlah & 43 & 100.0 \\
\hline
\end{tabular}

\subsection{PERBINCANGAN KAJIAN}

Perbincangan hasil dapatan kajian menunjukkan Gamifikasi Global Halal Game (GHG) mampu meningkatkan keberkesanan latihan peserta Professional Halal Training Programme kerana peserta didedahkan dengan Pembelajaran Aktif yang melibatkan penyertaan pelajar dalam proses PdP atau latihan. Selain itu, melalui Gamifikasi GHG juga dapat meningkatkan pengetahuan dan Page | 56 
pemahaman tinggi mereka terhadap ilmu Halal melalui soalan-soalan uji minda yang terbahagi kepada tiga aras kesukaran. Gambar-gambar grafik berwarna yang terdapat pada papan Gamifikasi GHG ini menyebabkan minat peserta Professional Halal Training Programme ini lebih meningkat. Melalui penguasaan teori ilmu halal yang diperolehi ketika menjawab soalan-soalan daripada Kad Uji Halal 1-3 dan Kad Halal Audit yang esklusif untuk Eksekutif Halal memberi peluang kepada peserta untuk meningkatkan kemahiran mereka dalam ilmu Halal. Ini kerana, kandungan Gamifikasi GHG ini merangkumi sukatan pelajaran Professional Halal Training Programme dan hampir semua topik ilmu Halal disentuh dan dipersembahkan dalam bentuk gamifikasi. Majoriti peserta program latihan ini juga bersetuju bahawa Gamifikasi GHG merupakan alternatif bahan pendidikan permainan Islamik dan sangat sesuai dijadikan bahan didik libur dalam latihan.

Selain itu, ciri-ciri fizikal Gamifikasi GHG juga memberi nilai tambah seterusnya menjadi daya penarik kepada peserta Professional Halal Training Programme untuk mendalami ilmu Halal secara santai. Dari segi saiz permainan dan saiz teks, walaupun agak besar namun ianya memudahkan tulisan papan Gamifikasi dibaca dengan jelas. Majoriti peserta Professional Halal Training Programme suka dengan grafik dan ilustrasi yang terdapat pada manual permainan, papan permainan, Kad Uji Halal, Kad Halal Audit, Kad Perintah dan Logo Halal JAKIM. Konsep permainan GHG ni sangat menarik dan amat unik walaupun tempoh menunggu dan bermain mengambil masa yang agak lama. Dalam pada itu, walaupun peraturan permainan GHG dan aras soalan uji mindanya agak sukar ironinya tahap interaksi sesama peserta Professional Halal Training Programme ketika bermain GHG begitu aktif sehingga menimbulkan minat dan keinginan yang tinggi untuk bermain lagi. Justeru, ciri-ciri fizikal Gamikasi GHG yang menarik dan impak keberkesanannya yang positif membuktikan bahawa bahan didik libur ini sangat sesuai untuk dijadikan bahan latihan.

\subsection{KESIMPULAN}

Di antara dapatan kajian yang diperolehi khususnya terhadap ciri-ciri fizikal Global Halal Game adalah seramai $90.7 \%$ responden tertarik dengan grafik dan ilustrasi papan permainan ini. Selain itu, majoriti responden bersetuju saiz teks yang digunakan pada papan permainan ini adalah besar. Di samping itu, hampir 100\% responden bersetuju terhadap Global Halal Game sebagai bahan didik hibur. Sebagai kesimpulan, inovasi yang diperkenalkan dalam bidang halal seperti Global Halal Game mampu menjadi model dan panduan khusus kepada para ilmuan dan umat Islam untuk mencipta kaedah penyampaian ilmu Islam yang lebih kreatif dan efektif.

\section{Penghargaan}

Sekalung penghargaan kepada pihak yang terlibat di dalam kajian ini secara langsung atau tidak langsung. Kajian ini dibiayai oleh geran PRGS yang bertajuk: "Pembangunan Prototaip Gamifikasi Global Halal Game (GHG) Dalam Pendidikan Islam Bagi Kompetensi Pelajar Dan Eksekutif Halal”, kod penyelidikan: USIM/PRGS/INFAD/055002/50219.

\section{Bibliografi}

Ahmad Mahdzan Ayob. (2005). Kaedah Penyelidikan Sosio Ekonomi (Edisi Ketiga). Kuala Lumpur: Dewan Bahasa dan Pustaka.

Azman Mahmud. (2016). Utusan Online. Diakses pada 4 April 2016. Malaysia Kini Peneraju Industri Halal. http://www.utusan.com.my/bisnes/ekonomi/malaysia-kini-peneraju-industri-halal-1.208304.

Cugelman, Brian. (2013). Gamification: What It Is and Why It Matters to Digital Behavior Change Developers. JMIR Serious Games, 1(1), 1.

Page $\mid 57$ 
Hamari, J., Koivisto, J., \& Sarsa, H. (2014). Does Gamification Work? - A Literature Review of Empirical Studies on Gamification. In Proceedings of the 47th Hawaii International Conference on System Science. Hawaii, USA, January 6-9, 2014.

Huotari, K., \& Hamari, J. (2012). Defining Gamification - Service Marketing Perspective. In Proceedings of the 16 $6^{\text {th }}$ International Academic Mindtrek Conference. Tampere, Finland. October 3-5, 2012.

Hussain, S. Y. S., Tan, W. H., \& Idris, M. Z. (2014). Digital Game-Based Learning for Remedial Mathematics Students: A New Teaching And Learning Approach In Malaysia. International Journal of Multimedia Ubiquitous Engineering, 9(11), 325-338.

Hsin-Yuan Huang, W., \& Soman, D. (2013). A Practitioner's Guide To Gamification Of Education. Toronto, Canada: Rotman School of Management.

Lim Chong Hin. (2007). Penyelidikan Pendidikan: Pendekatan Kuantitatif dan Kualitatif. Mc-Graw-Hill Education.

Mohammad Aizat Jamaluddin, Mohd Anuar Ramli, Mariam Abdul Latif, Dzulkifly Mat Hashim, Suhaimi Ab Rahman. (2012). Pendidikan Kepenggunaan Halal di Malaysia. Konferensi Antarabangsa Islam Borneo V. Brunei.

Mohd Mahyeddin Mohd Salleh, Mohammad Najib Jaffar. (2019). Halal Haram Haiwan Menurut Islam Dan Fatwa Di Malaysia. Nilai: Penerbit USIM.

Mohd Majid Konting. (2004). Kaedab Penyelidikan Pendidikan. Kuala Lumpur: Dewan Bahasa dan Pustaka.

Noor, N. M., Yusoff, F. H., \& Lob, R. (2015). The Potential Use of Augmented Reality In Gamification. International Computing and Informatics, 159-167.

Nurkhamimi Zainuddin, Azman Ab. Rahman, Zahari Mahad Musa, Norlina Ismail, Siti Zulaiha Mokhtar. (2017). Inovasi Gamifikasi Global Zakat Game Dalam Pendidikan Islam. Dalam Memperkasa Kutipan dan Agihan Zakat di Malaysia. 355-370.

Nur Sharieza Ismail. (2018). Kampus Uols. Diakses pada 24 Disember 2018. Penyelidik USIM Cipta Permainan Berkonsep Gamifikasi, Pupuk Kesedaran Halal. https://kampusuols.com/article/423879/U-Inovasi/Penyelidik-Usim-cipta-permainanberkonsep-gamifikasi-pupuk-kesedaran-halal.

Othman Talib. (2013). Asas Penulisan Tesis, Penyelidikan \& Statistik. Serdang: Universiti Putra Malaysia Press.

Rohaila Mohamed Rosly \& Khalid, F. (2017). Gamifikasi: Konsep dan Implikasi dalam Pendidikan. Dalam Rohaila Mohamed Rosly, Nabila Atika Razali \& Nur Atikah Jamilluddin. (Editor)., Pembelajaran Abad ke-21: Trend Integrasi Teknologi. 144-154. Bangi: Universiti Kebangsaan Malaysia.

Rohaniza Idris, BH Online. 23 Ogos 2017. Malaysia Peneraju Pasaran halal DuniaTPM.https://www.bharian.com.my/berita/nasional/2017/08/316552/malaysia-penerajuipasaran-halal-dunia-tpm. 